\title{
Progressive Disorganization of Paranodal Junctions and Compact Myelin Due to Loss of DCC Expression by Oligodendrocytes
}

\author{
Sarah-Jane Bull, ${ }^{1 *}$ Jenea M. Bin, ${ }^{1 *}$ () Eric Beaumont, ${ }^{3}{ }^{\circledR}$ Alexandre Boutet, ${ }^{2}$ Paul Krimpenfort, ${ }^{4}$ Abbas F. Sadikot, ${ }^{2}$ \\ and Timothy E. Kennedy ${ }^{1}$ \\ 1Department of Neurology and Neurosurgery and ${ }^{2}$ Cone Laboratory, Montréal Neurological Institute, McGill University, Montréal, Québec, Canada, H3A \\ 2B4, ${ }^{3}$ Département de Chirurgie, Université de Montréal, Montreal, Quebec, Canada, H3C 3J7, and ${ }^{4}$ Department of Molecular Genetics, Cancer Genomics \\ Centre, Centre for Biomedical Genetics, Netherlands Cancer Institute, Amsterdam 1066 CX, The Netherlands
}

Paranodal axoglial junctions are critical for maintaining the segregation of axonal domains along myelinated axons; however, the proteins required to organize and maintain this structure are not fully understood. Netrin-1 and its receptor Deleted in Colorectal Cancer (DCC) are proteins enriched at paranodes that are expressed by neurons and oligodendrocytes. To identify the specific function of DCC expressed by oligodendrocytes in vivo, we selectively eliminated DCC from mature myelinating oligodendrocytes using an inducible cre regulated by the proteolipid protein promoter. We demonstrate that DCC deletion results in progressive disruption of the organization of axonal domains, myelin ultrastructure, and myelin protein composition. Conditional DCC knock-out mice develop balance and coordination deficits and exhibit decreased conduction velocity. We conclude that DCC expression by oligodendrocytes is required for the maintenance and stability of myelin in vivo, which is essential for proper signal conduction in the CNS.

Key words: caspr; DCC; myelin; netrin; oligodendrocyte; paranode

\section{Introduction}

Axonal myelination is a key mechanism that increases the speed of nerve transmission in vertebrates; however, the complexity of myelin, both structurally and metabolically, renders it particularly vulnerable to damage and deficits that give rise to various forms of dysmyelinating and demyelinating diseases. The rapid saltatory conduction of action potentials along a myelinated axon depends on the precise organization of specialized subcellular domains: the node of Ranvier, the paranode, the juxtaparanode, and the internode.

The paranode, located on both sides of the node, is the region where each layer of the myelin sheath terminates in a cytoplasmfilled membrane loop that tightly adheres to the axon. Several proteins are known to be enriched at paranodes and mediate

\footnotetext{
Received Jan. 31, 2014; revised May 27, 2014; accepted June 11, 2014.

Author contributions:S.-J.B. and T.E.K. designed research;S.-J.B., J.M.B., E.B., and A.B. performed research; P.K., A.F.S., and T.E.K. contributed unpublished reagents/analytic tools; S.-J.B., J.M.B., and E.B. analyzed data; S.-J.B., J.M.B., and T.E.K. wrote the paper.

This work was supported by grants from the Multiple Sclerosis Society of Canada and Canadian Institutes of Health Research. S.-J.B. was supported by a Multiple Sclerosis Society of Canada studentship, J.M.B. by a Vanier Canada Graduate scholarship, and T.E.K. by a Scholarship from the Killam Trust and by a Chercheur Nationaux Award from the Fonds de la Recherche en Santé du Québec. We thank Sathy Rajasekharan for comments on this manuscript and Thomas Stroh and Jeannie Mui for guidance related to electron microscopy.

*S.-J.B. and J.M.B. contributed equally to this work.

The authors declare no competing financial interests.

Correspondence should be addressed to Timothy E. Kennedy, Ph.D., Departments of Neurology and Neurosurgery, Montreal Neurological Institute, McGill University, 3801 University Avenue, Montreal, Quebec, Canada, H3A 2B4. E-mail: timothy.kennedy@mcgill.ca.

DOI:10.1523/JNEUROSCI.0448-14.2014

Copyright $\odot 2014$ the authors $\quad 0270-6474 / 14 / 349768-11 \$ 15.00 / 0$
}

paranodal axoglial interactions, including Caspr, contactin, neurofascin-155 (nfasc155), $\alpha \mathrm{II}$ - and $\beta \mathrm{II}-$ spectrin, protein 4.1B, and ankyrinB (for review, see Buttermore et al., 2013). The axonal proteins Caspr and contactin and the glial protein nfasc155 are key players at the axoglial septate-like junctions, and disruption of the expression of any of these proteins results in disorganized paranodes, behavioral deficits, and reduced axon conduction velocity (Bhat et al., 2001; Boyle et al., 2001; Sherman et al., 2005; Pillai et al., 2009).

Components of noncompact myelin membranes also contribute to paranode and myelin integrity, including CNP (LappeSiefke et al., 2003), myelin-associated glycoprotein (MAG; Fruttiger et al., 1995), and galactolipids (Coetzee et al., 1996; Dupree et al., 1998). In addition, several intracellular signaling molecules including cdc42 and rac1 have been demonstrated to influence myelin architecture (Thurnherr et al., 2006). Thus, myelin formation and stability depend on multiple factors acting in concert to maintain this highly specialized cellular structure.

Netrin-1 and the netrin receptor Deleted in Colorectal Cancer (DCC) are enriched in noncompact myelin membranes (Manitt et al., 2001), particularly at paranodes (Jarjour et al., 2008). Conventional DCC or netrin-1 null knock-out mice die within a few hours after birth (Serafini et al., 1996; Fazeli et al., 1997), limiting their utility for studying myelination in vivo. Previous studies performed in vitro using organotypic cerebellar slice cultures provided evidence that DCC and netrin- 1 are not required for the initial formation of compact myelin or paranodal junctions, but rather contribute to maintain axonal domain segregation and 
appropriate paranode ultrastructure (Jarjour et al., 2008). In the adult mammalian CNS, both neurons and oligodendrocytes express netrin-1 and DCC (Manitt et al., 2001, 2004); however, the cellular source of these proteins required for paranode maintenance is not known.

To identify the functional significance of DCC expressed by oligodendrocytes in vivo, we generated mice in which DCC expression was selectively deleted from mature oligodendrocytes. This resulted in progressive disruption of paranodes and compact myelin, reduced conduction velocity, and deficits in coordination and balance. We conclude that DCC expression by oligodendrocytes is essential for the maintenance of myelin in vivo, and that myelin abnormalities caused by the absence of DCC result in deficits in axonal conduction velocity and behavior.

\section{Materials and Methods}

Animals. DCC ${ }^{\text {flox/flox }}$ mice were developed to enable cre-mediated excision of exon 23, encoding the DCC transmembrane domain, as described previously (Krimpenfort et al., 2012). PLPcreER ${ }^{\mathrm{T}}$ mice (Doerflinger et al., 2003) were obtained from Dr. Samuel David (McGill University, Montreal, Canada). Conventional $d c c$ knock-out mice (Fazeli et al., 1997) were obtained from Dr. Robert Weinberg (Whitehead Institute for Biomedical Research, Cambridge, MA), and extensively backcrossed into a CD-1 genetic background. CMVcre mice (Schwenk et al., 1995) were provided by Dr. David Colman (McGill University, Montreal, Canada). ROSA26-lacZ reporter mice (Soriano, 1999) were provided by Dr. JeanFrançois Cloutier (McGill University, Montreal, Canada). All procedures were performed in accordance with the Canadian Council on Animal Care guidelines for the use of animals in research.

Tamoxifen induction. Tamoxifen (Sigma; T5648) was dissolved in a 10:1 mixture of sunflower oil/ethanol at a concentration of $10 \mathrm{mg} / \mathrm{ml}$. An intraperitoneal injection of tamoxifen, $1 \mathrm{mg}$ in $0.1 \mathrm{ml}$, was delivered twice a day for 5 consecutive days in the test group, as well as the control littermates. Injections were performed between 4.5 and 6 weeks of age. All animals used were males.

Antibodies. The following antibodies were used in this study: mouse monoclonal anti-Caspr (UCDavis/NIH NeuroMab Facility; catalog \#75001, RRID:AB_2083496), rabbit polyclonal anti-Kv1.2 (Alomone Labs; catalog \#APC-010, RRID:AB_2040146), rabbit polyclonal anti-NFM (Millipore; catalog \#AB1987, RRID:AB_91201), goat polyclonal antiDCC (Santa Cruz Biotechnology; catalog \#SC6535, RRID:AB_2245770), mouse monoclonal anti-DCC (BD Biosciences; catalog \#554223, RRID: AB_395314), rabbit polyclonal anti-calnexin (BioVision; catalog \#3811100, RRID:AB_2069013), rabbit polyclonal anti-MAG and mouse monoclonal anti-PLP (a gift from Dr. David Colman, McGill University), rabbit polyclonal anti-nfasc (Tait et al., 2000; a gift from Dr. Peter Brophy, University of Edinburgh), rat polyclonal anti-MBP (Millipore; catalog \#MAB386, RRID:AB_94975), rabbit polyclonal anti-GAPDH (Santa Cruz Biotechnology; catalog \#Sc-25778, RRID:AB_641106), mouse monoclonal anti-CNP (Abcam; catalog \#ab24566, RRID: AB_2260805), rabbit polyclonal anti-olig2 (Abcam; catalog \#ab81093, RRID:AB_1640746), and mouse monoclonal anti-APC (CC1; Abcam; catalog \#ab16794, RRID:AB_443473). Secondary antibodies used were Alexa 546-conjugated goat anti-mouse (Invitrogen; catalog \#A11003, RRID:AB_141370) and goat anti-rabbit (Invitrogen; catalog \#A11010, RRID:AB_143156), Alexa 488-conjugated goat anti-rabbit (Invitrogen; catalog \#A11008, RRID:AB_143165), HRP-conjugated donkey anti-goat (Cedarlane; catalog \#705-035-147), donkey anti-rat (Cedarlane; catalog \#712-035-153), donkey anti-mouse (Cedarlane; catalog \#715-035-150), and donkey anti-rabbit (Cedarlane; catalog \#711-035-152).

Immunohistochemistry. For the analysis of adult PLPcreER ${ }^{\mathrm{T}} \mathrm{DCC}^{\text {flox/flox }}$ mice, animals were deeply anesthetized and perfused with phosphate buffered saline, $\mathrm{pH} 7.4$, (PBS) followed by 4\% PFA. Brain and spinal cord were dissected, postfixed in 4\% PFA for $1 \mathrm{~h}$, and equilibrated in $30 \%$ sucrose at $4^{\circ} \mathrm{C}$. After embedding in optimal cutting temperature compound (Sakura Finetek), $16 \mu \mathrm{m}$ sections were cut on a cryostat. For the study of CMVcreDCC flox/flox mice, embryos were fixed in Carnoy's so- lution (60\% ethanol, $30 \%$ chloroform, and $10 \%$ acetic acid), dehydrated, and embedded in paraffin. Eight micrometer sections were cut and processed for staining. After blocking in 3\% BSA, 0.3\% Triton X-100 in PBS, primary antibodies were added (diluted in blocking solution), incubated overnight at $4^{\circ} \mathrm{C}$, and rinsed with PBS. Sections were then incubated with secondary antibodies, along with phalloidin and/or Hoechst when needed, before washing and mounting with Fluoromount-G (Southern Biotech). Images were captured with a MagnaFire CCD camera (Optronics) and an Axiovert 100 microscope (Carl Zeiss). For paranode analysis, images were captured using a Zeiss LSM 510 confocal microscope and quantified using LSM510 software by an experimenter blind to experimental conditions. The length of the Caspr-immunoreactive domain was normalized to the width of Caspr at the paranode. The average width of Caspr-immunoreactive domains did not differ between groups.

$X$-gal staining. Ten days after tamoxifen administration, PLPcreER ${ }^{\mathrm{T}+}$ ROSA26 mice were anesthetized and perfused with PBS, followed by $4 \%$ PFA containing $2 \mathrm{~mm} \mathrm{MgSO}_{4}$, and $5 \mathrm{~mm}$ EGTA. Brain and spinal cord sections, $16 \mu \mathrm{m}$ thick, were then rapidly processed for $\mathrm{X}$-gal staining as described previously (Mombaerts et al., 1996).

Electron microscopy. Mice were deeply anesthetized and perfused with $0.1 \mathrm{M}$ phosphate buffer, $\mathrm{pH} 7.4$, followed by $2.5 \%$ glutaraldehyde with $2 \%$ PFA, and then by $2 \%$ PFA. Tissue was dissected and postfixed for 1 week at $4^{\circ} \mathrm{C}$, rinsed with buffer, and postfixed in $2 \%$ osmium tetroxide for 40 min. Fixed tissue was then dehydrated through a graded ethanol series and embedded in Epon. Ultrathin sections (70-100 nm) were prepared, placed onto 200 mesh copper grids, and stained with $4 \%$ uranyl acetate for $5 \mathrm{~min}$, followed by Reynold's lead citrate for $3 \mathrm{~min}$. Images were captured using a transmission electron microscope at $120 \mathrm{kV}$ equipped with a Tecnai 12 (FEI) Gatan BioScan CCD camera.

Measurement of g-ratios. The $g$-ratios (axon diameter/fiber diameter) were calculated with a $g$-ratio calculator plug-in for ImageJ (available on-line at http://gratio.efil.de/) applied to electron microscopy images of coronal sections of optic nerves. Sixty myelinated axons per animal were randomly selected for measurement (six animals per group, for a total of 360 axons per genotype). Mice were 6 months or 9 months post induction. No effect of age was detected.

Outfolding quantification. The number of axons with myelin outfoldings was counted from 10 electron micrograph images taken at random from cross sections of optic nerve. Percentages were calculated based on the total number of myelinated axons in these images. In total, between 5000 and 6000 axons were examined per animal with three animals per group. The length of the myelin outfoldings were measured using ImageJ software (RRID:nif-0000-30467; http://imagej.nih.gov/ij/).

Behavioral testing. Open-field tests were performed in a square open field $(50 \times 50 \mathrm{~cm})$ surrounded by $30 \mathrm{~cm}$ high walls. After a $20 \mathrm{~min}$ habituation period, recordings of individual mouse movements were performed for $2 \mathrm{~h}$ using VideoTrack software (ViewPoint Life Sciences). The hanging wire grip test was performed, as described previously (Sango et al., 1996), to test overall muscle strength. Briefly, mice were put on a cage lid held upside down and the time that each mouse was able to grip to the wires without falling was recorded. A cutoff time was set at $60 \mathrm{~s}$. The balance beam test was performed as previously described (Carter et al., 1999) to assess general balance and coordination. Briefly, mice were trained for 4 consecutive days to cross a narrow beam $(0.8 \mathrm{~cm}$ diameter, $50 \mathrm{~cm}$ long) and reach an enclosed safety platform. On the fifth day, the time taken by each mouse to cross the beam was recorded; with a cutoff time set at $60 \mathrm{~s}$. Accelerating rotarod (Rotamex; $3 \mathrm{~cm}$ rod diameter, gray PVC with a knurled finish) testing was performed after 3 consecutive days of training. During each training session, the mice received five trials on an accelerating rotarod (1-24 rpm) for a maximum of $150 \mathrm{~s}$. On the test day, mice were tested on an accelerating $\operatorname{rod}(1 \mathrm{rpm} / 5 \mathrm{~s})$ that reached a maximum speed of $24 \mathrm{rpm}$. Mice were allowed between three and five trials with a rest of at least $20 \mathrm{~min}$ between each trial. The latency to fall was recorded, with a cutoff time of $300 \mathrm{~s}$.

Brain lysates and Western blotting. Embryonic day 14 (E14) brains were lysed in RIPA buffer (10 mm phosphate buffer, pH 7.2, $150 \mathrm{~mm} \mathrm{NaCl}, 1 \%$ NP- $40,0.5 \%$ sodium deoxycholate, and $0.1 \%$ SDS) containing protease inhibitors. Adult brain tissue was lysed in 3\% Triton X-100 buffer $(20 \mathrm{~mm}$ Tris, pH 8, $150 \mathrm{~mm} \mathrm{NaCl}, 10$ mм EGTA, 10 mm EDTA, and 3\% Triton 
A
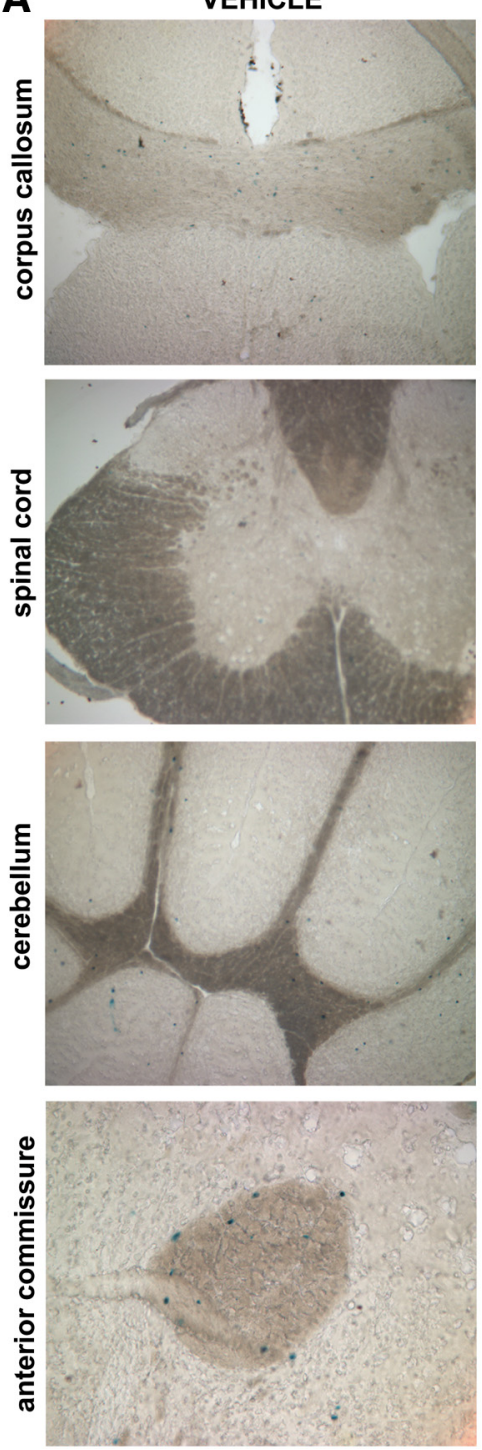

TAMOXIFEN
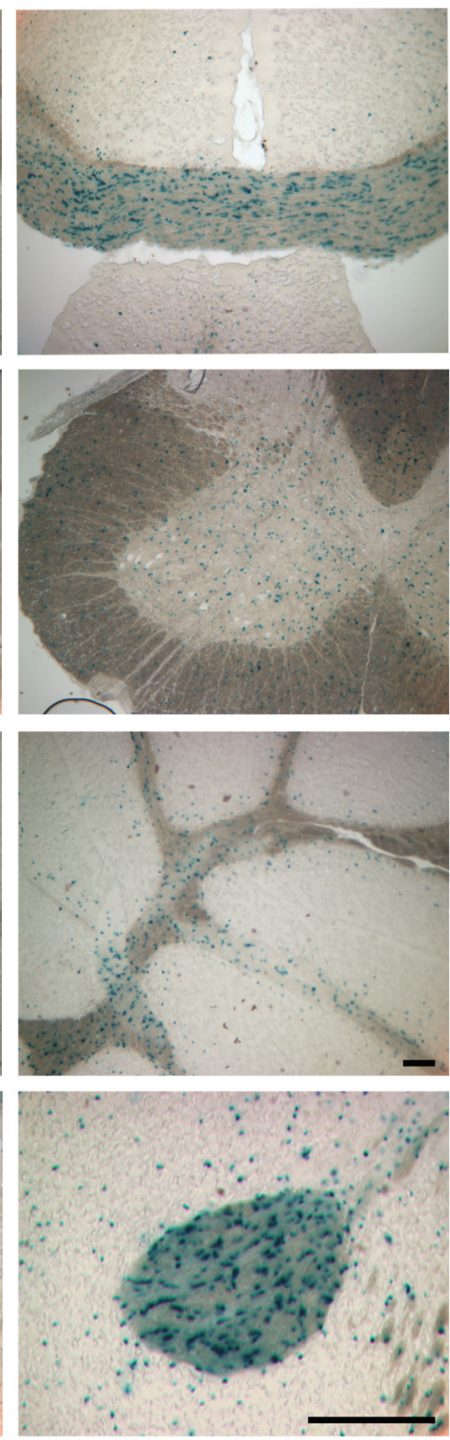

B

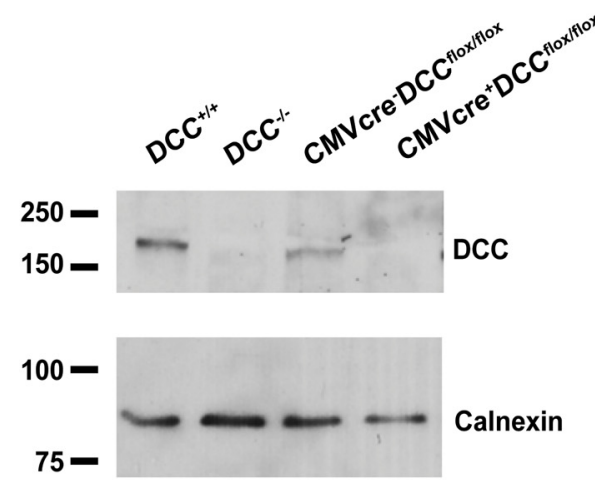

\section{C}
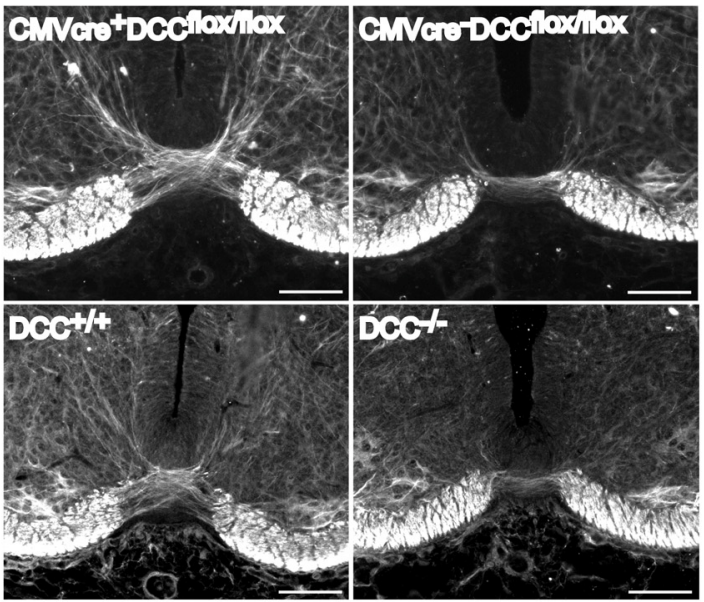

D

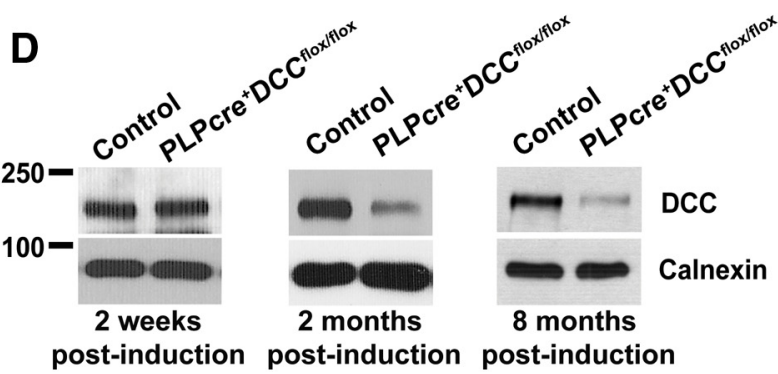

Figure 1. Validation of mouse lines. Cre-mediated recombination of the floxed DCC allele ablates expression of a functional DCC protein. $\boldsymbol{A}$, Validation of the tamoxifen-induction protocol (1 mg, i.p.; twice a day for 5 consecutive days) was performed by crossing PLPcreER ${ }^{\top}$ mice to ROSA26-lacZ mice. Successful cre recombination was observed based on robust $\beta$-gal expression in white matter tracts. Scale bar, $200 \mu \mathrm{m} . \boldsymbol{B}, \mathrm{DCC} \mathrm{flox}^{\text {flox }}$ mice were bred to CMVcre mice to induce ubiquitous recombination. Phenotypes were compared with conventional DCC null mice. No DCC protein was detected in brain lysates of E14 CMV cre ${ }^{+} D C C^{\text {flox/flox }}$ and DCC ${ }^{-1-}$ embryos. C, Neurofilament M staining showing that CMV cre ${ }^{+} D C C^{\text {flox/flox }}$ embryos have a thinner spinal cord ventral commissure compared with littermate controls at E14. A similar phenotype was observed in E14 DCC ${ }^{-1-}$ spinal cord. Scale bar, $100 \mu \mathrm{m}$. D, DCC protein expression in cerebellar lysates. Two weeks after induction, no differences in DCC protein levels were detected. Two months after induction, a reduction in DCC protein levels was observed, which remained decreased 8 months after induction.

$\mathrm{X}-100)$ containing protease inhibitors, to maximize myelin membrane solubilization. Proteins were separated by SDS-PAGE, transferred onto nitrocellulose membrane (GE Healthcare), and assayed by Western blotting. Densitometric analysis was performed using Adobe Photoshop. Values were normalized to loading control values for GAPDH. To minimize variability, each PLPcreER ${ }^{\mathrm{T}+}$ DCC $^{\text {flox/flox }}$ mouse was compared with a control littermate. Five mice of each genotype were used in the analysis.

Cell number count. Sections of optic nerve and spinal cord from animals 9 months post induction were immunolabeled for $\mathrm{CC} 1$ and Olig2, both markers of oligodendrocytes. Pictures of randomly selected fields were taken (three fields of view per animal; three animals per genotype) and CC1/Olig2 double-positive cells counted.

Conduction velocity analysis. For terminal surgical experiments mice were anesthetized with a single intraperitoneal injection of a solution of $10 \%$ urethane at $2 \mathrm{~g} / \mathrm{kg}$. Mice were then transferred to a stereotaxic frame with body temperature maintained at $37^{\circ} \mathrm{C}$ using a feedback-controlled heating blanket. To assess the somatosensory response, EMG electrodes on the right hamstring were used for stimulation, with a current of $0.5-2$
$\mathrm{mA}$ delivered in three pulses of $0.1 \mathrm{~ms}$ duration and a $1 \mathrm{~ms}$ delay between pulses. Stimulation intensity was set at two times muscle threshold. A hole was made in the skull over the left somatosensory cortex that responds to the hindlimb region and a $\pm 1 \mathrm{M} \Omega$ tungsten microelectrode inserted through the dura to record field potential amplitudes following the hamstring stimulation. A reference electrode was positioned under the skin on the posterior portion of the neck. Spike 2 neuronal software (CED) was used to acquire and analyze the data. EEG field potential and EMG responses were measured for latency, at the start of the first stimulating pulse to the first deflection of the responses from baseline in either direction.

\section{Results}

Validating an inducible, oligodendrocyte-specific DCC knock-out

To identify the consequences of loss of DCC function on myelin maintenance in vivo, we used a cre/loxP gene-targeting strategy to eliminate DCC from mature oligodendrocytes. Since signaling 
A

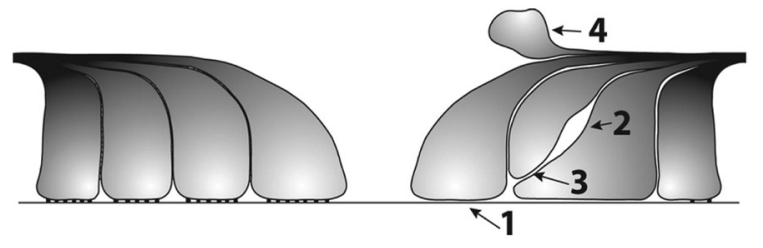

B
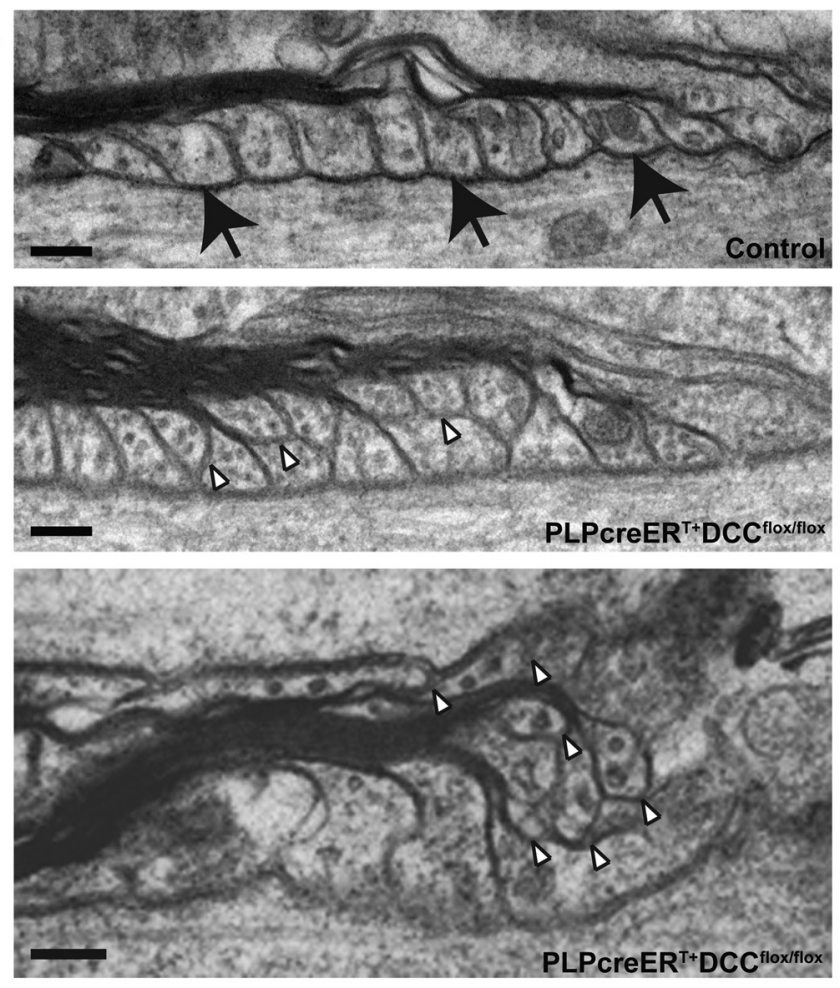

C

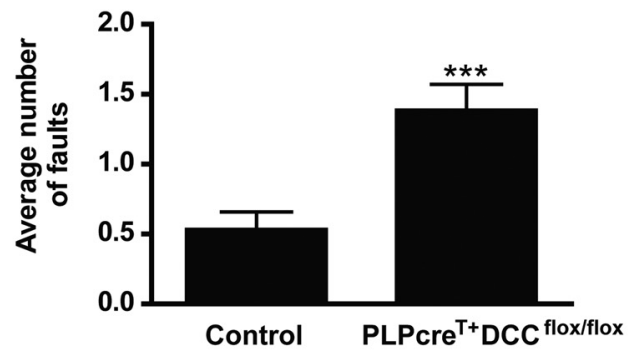

D

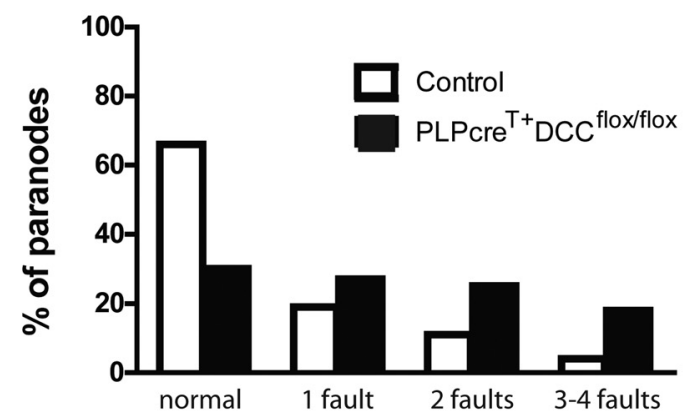

E

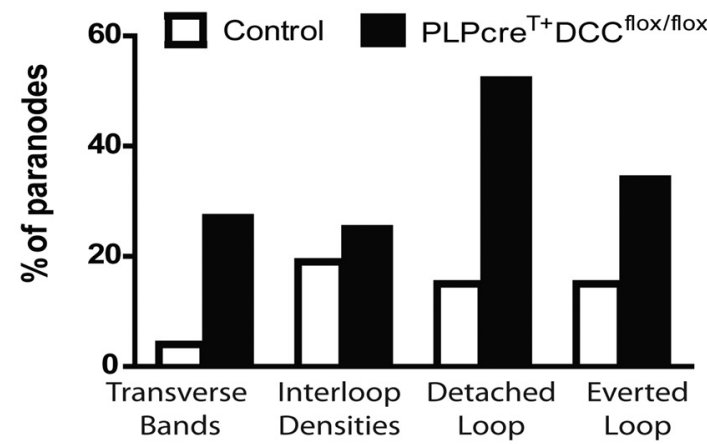

Figure 2. Paranodal architecture becomes disrupted in PLPcreER ${ }^{T+} D C C{ }^{\text {flox/flox }}$ mice. $A$, Paranodes were scored according to four faults: absence of transverse bands (1), absence of interloop densities (2), detached loops (3), and everted loops (4). B, Example of paranodes in control and PLPcreER ${ }^{T+} D C C{ }^{\text {flox/flox }}$ optic nerve. The majority of control paranodes exhibit normal loops contacting the axon and visible transverse bands (black arrows), whereas the majority of knock-out paranodes were abnormal. White arrowheads display glial loops that do not contact the axon. Scale bar, 0.1 $\mu \mathrm{m}$. C, At 6 months after induction, PLPCreER ${ }^{T+}$ DCC floxfflox paranodes display more faults per paranode than control paranodes ${ }^{* * *} p=0.0002$; two-tailed Student's $t$ test). D, The majority of control paranodes are normal while the majority of PLPcreER ${ }^{T+} D C C^{\text {flox/flox }}$ paranodes are abnormal, bearing one or more faults. $E$, Prevalence of each type of fault in PLPcreER ${ }^{T+} D C C^{\text {flox/flox }}$ paranodes compared with controls. For all graphs $n=44-47$ paranodes; three different animals were assessed per genotype.

downstream of DCC regulates oligodendrocyte precursor cell (OPC) migration (Jarjour et al., 2003; Tsai et al., 2003), OPC process retraction (Rajasekharan et al., 2010), and process branching by oligodendrocytes (Rajasekharan et al., 2009), we avoided disrupting initial oligodendrocyte development by crossing DCC $\mathrm{DCx}^{\text {floflox }}$ mice to the PLPcreER ${ }^{\mathrm{T}}$ mouse line. This allowed temporal regulation of the excision of the floxed DCC sequence by injection of tamoxifen to induce cre translocation into the nucleus (Doerflinger et al., 2003). To study loss of function specifically in oligodendrocytes, the age at which recombination is induced is critical when using the PLPcreER ${ }^{\mathrm{T}}$ mouse line. Before P16, the proteolipid protein (PLP) promoter is active in oligodendrocytes, Schwann cells, and some neurons; however, after 3 weeks of age, the PLP promoter induces cre expression exclusively in oligodendrocytes (Michalski et al., 2011). In our study, recombination was induced between 4.5 and 6 weeks of age, when myelination is nearly complete in the rodent CNS (Foran and Peterson, 1992; Hamano et al., 1998; Richardson et al., 2011).

To confirm that the injection protocol ( $1 \mathrm{mg}$ tamoxifen twice a day for 5 consecutive days) induced efficient recombination,
PLPcreER ${ }^{\mathrm{T}}$ mice were crossed with ROSA26-lacZ mice, in which the $\beta$-gal reporter is expressed as a result of cre-mediated recombination (Araki et al., 1995). In PLPcreER ${ }^{\mathrm{T}+}$ ROSA26-lacZ mice, high expression of the reporter protein was detected in cells of all CNS white matter tracts examined within $10 \mathrm{~d}$ after the end of the tamoxifen injection regimen, but not following injection with vehicle (Fig. 1A). Consistent with Michalski et al. (2011), lacZ expression was not detected by Schwann cells in peripheral nerve. In all subsequent experiments, control littermates (PLPcreER ${ }^{\mathrm{T}-} \mathrm{DCC}^{\text {flox/flox }}$ and PLPcreER ${ }^{\mathrm{T}+} \mathrm{DCC}^{\mathrm{w} / \mathrm{w}}$ ) were submitted to the same tamoxifen regimen as the PLPcreER ${ }^{\mathrm{T}+} \mathrm{DCC}^{\text {flox/flox }}$ group to account for any indirect effects of tamoxifen. Only males were used to avoid possible variability due to gender.

To confirm that cre-mediated recombination of DCC loxP sites disrupts DCC function, we initially crossed DCC ${ }^{\text {flox/flox }}$ mice with CMVcre mice in which cre expression is regulated by a human CMV promoter. The CMV promoter results in ubiquitous cre expression before the implantation stage of embryonic development (Schwenk et al., 1995). Thus, loss of DCC expression is anticipated in all cells and CMV cre ${ }^{+} \mathrm{DCC}^{\text {flox/flox }}$ embryos 
are expected to phenocopy conventional $\mathrm{DCC}^{-1-}$ embryos. At E14, DCC protein was not detected in $\mathrm{CMV} \mathrm{Cre}^{+} \mathrm{DCC}^{\text {flox/flox }}$ brain lysates (Fig. 1B). To confirm the cre-mediated loss of DCC function, we examined the formation of the spinal cord ventral commissure in the $\mathrm{CMV} c \mathrm{Cr}^{+} \mathrm{DCC}^{\text {flox/flox }}$ embryos, which is reduced in conventional DCC knock-out mice (Fazeli et al., 1997). At E14, the spinal ventral commissure of $\mathrm{CMVcre}^{+} \mathrm{DCC}^{\text {flox/flox }}$ embryos was substantially thinner than in $\mathrm{CMV} \mathrm{Cre}^{-} \mathrm{DCC}^{\text {flox/flox }}$ littermates, phenocopying the deficit in conventional E14 DCC knock-out mice (Fig. 1C). These results demonstrate that cremediated deletion of DCC results in loss of DCC protein function.

\section{DCC expression and turnover in} PLPcreER $^{\mathrm{T}+}$ DCC $^{\text {flox/flox }}$ mice

To assess the loss of DCC expression by oligodendrocytes in PLPcreER ${ }^{\mathrm{T}+}$ DCC $^{\text {flox/flox }}$ mice, Western blots were used to assay protein lysates of cerebellum, a brain region rich in white matter. At 2 weeks after induction DCC protein levels did not differ between PLPcreER ${ }^{\mathrm{T}+}{ }^{\mathrm{DCC}}{ }^{\text {flox/flox }}$ mice and their control littermates. In contrast, 2 months after induction, DCC protein levels had decreased in PLPcreER ${ }^{\mathrm{T}+} \mathrm{DCC}^{\text {flox/flox }}$ mice (Fig. 1D), indicating that DCC made by oligodendrocytes has a relatively slow turnover, similar to other proteins localized to paranodal junctions (Hedstrom et al., 2008). DCC protein levels remained low 8 months after induction (Fig. 1D). As expected, not all DCC protein was eliminated, since DCC is also expressed by neurons in the adult CNS (Manitt et al., 2001, 2004; Shatzmiller et al., 2008). In light of the apparent long half-life of DCC in myelin and because we were interested in studying the effect of the absence of DCC on myelin maintenance, in subsequent experiments mice were examined at least 6 months after tamoxifen induction.

\section{Disruption of paranodal junctions in $\operatorname{PLPcreER}^{\mathrm{T}+} \mathrm{DCC}^{\text {flox/flox }}$ mice}

The absence of DCC expression in vitro causes a defect in the maintenance of paranodal ultrastructure (Jarjour et al., 2008), which is significantly more severe than the disorganization commonly observed with aging (Mierzwa et al., 2010; Shepherd et al., 2012). We examined paranodal ultrastructure by electron microscopy in sagittal sections of optic nerve from PLPcreER ${ }^{\mathrm{T}+}$ DCC $^{\text {flox/flox }}$ mice 6 months after tamoxifen induction. The degree of disorganization was assessed by scoring each paranode according to the presence or absence of the following four faults: lack of transverse bands, lack of interloop densities, membrane loops detached from the axon, or everted membrane loops (Fig. 2A).

Paranodes in PLPcreER ${ }^{\mathrm{T}+}$ DCC $^{\text {flox/flox }}$ mice had twice the number of faults compared with control mice of the same age (Fig. 2 B, C). While only $33 \%$ of control paranodes analyzed exhibited any fault, $70 \%$ of PLPcreER ${ }^{\mathrm{T}+} \mathrm{DCC}^{\text {flox/flox }}$ paranodes were scored as abnormal, with one or more faults (Fig. 2D). Detachment of glial loops from the axon was the most common fault detected with $52 \%$ of paranodes in PLPcreER ${ }^{\mathrm{T}+}$ DCC $^{\text {flox/flox }}$ mice exhibiting at least one glial loop that did not contact the axon, compared with $15 \%$ of paranodes in controls (Fig. $2 B, E$ ). In contrast, the absence of DCC expression by oligodendrocytes did not lead to a dramatic increase in the proportion of paranodes that displayed abnormal interloop densities or spacing between the loops (Fig. 2E; 19\% for controls versus 25\% for PLPcreER $\left.^{\mathrm{T}+} \mathrm{DCC}^{\text {flox/flox }}\right)$. Thus, loss of DCC function primarily disrupts interactions between the axon and oligodendrocyte rather than between oligodendrocyte membrane loops. We conclude that the CNS of PLPcreER ${ }^{\mathrm{T}+} \mathrm{DCC}^{\text {flox/flox }}$ mice exhibits
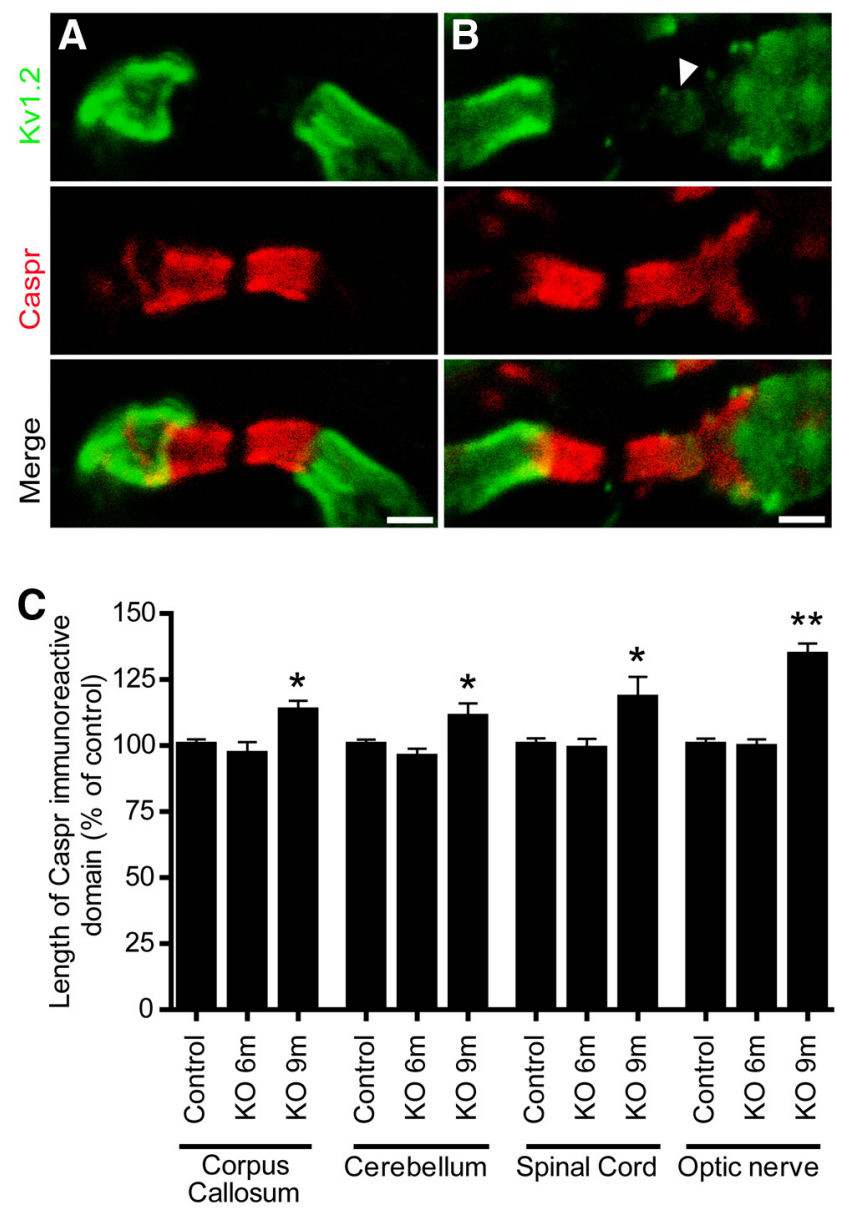

Figure 3. Progressive disorganization of paranodal domains in PLPCreER ${ }^{T+} D C C^{f l o x} / f l o x$ mice. Paranodal domain organization was assessed by measuring the length of the paranodal marker Caspr. Examples of spinal cord paranodes seen in control $(\boldsymbol{A})$ and PLPcreER ${ }^{T+}$ DC ${ }^{\text {flox/flox }}$ (B) mice 9 months after tamoxifen induction are depicted. Paranodal domains were visualized with Caspr antibodies and juxtaparanodal domains were visualized with potassium channel (Kv1.2) antibodies. Some paranodes displayed Caspr leaking out of the paranodes and Kv1.2 leaking into the paranodes ( $\boldsymbol{B}$; white arrowhead). $\boldsymbol{C}$, Quantification of the length of the Casprimmunoreactive domain. Caspr-immunoreactive domains are similar to controls 6 months after induction of PLPcreER ${ }^{T+} D C C^{\text {flox/flox }}$ mice $(K 06 \mathrm{~m})$, but lengthened 9 months after tamoxifen induction (K0 $9 \mathrm{~m})$ in the corpus callosum $(n=52-138)$, cerebellum $(n=84-205)$, spinal cord ( $n=84-194)$, and optic nerve $\left(n=150 ;{ }^{*} p<0.05,{ }^{* *} p<0.01\right.$; ANOVA with Tukey's post hoc test; three animals per genotype were analyzed at each time point). Scale bar, $2 \mu \mathrm{m}$. KO, knock-out.

paranodal ultrastructural defects within 6 months of loss of DCC gene expression.

Impaired maintenance of paranodal domain organization in PLPcreER $^{\mathrm{T}+}$ DCC $^{\text {flox/flox }}$ mice

Caspr is an axonal transmembrane protein, highly enriched at paranodes, which interacts with contactin in cis and with glial nfasc155 in trans (Bonnon et al., 2007). The absence of DCC in vitro resulted in diffusion of Caspr along the axon (Jarjour et al., 2008). This is thought to result from degeneration of the integrity of paranodal axoglial contacts, which allows unbound Caspr to diffuse along the axonal membrane away from the paranode.

To investigate axonal domain organization in PLPcreER ${ }^{\mathrm{T}+}$ DCC $^{\text {flox/flox }}$ mice, we measured the length of the Casprimmunoreactive domain at paranodes in corpus callosum, cerebellum, spinal cord, and optic nerve at both 6 and 9 months after tamoxifen induction (Fig. 3). We were surprised to find that 
A

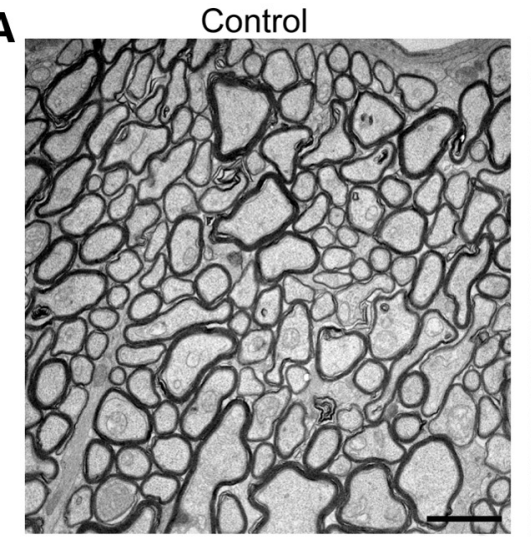

B
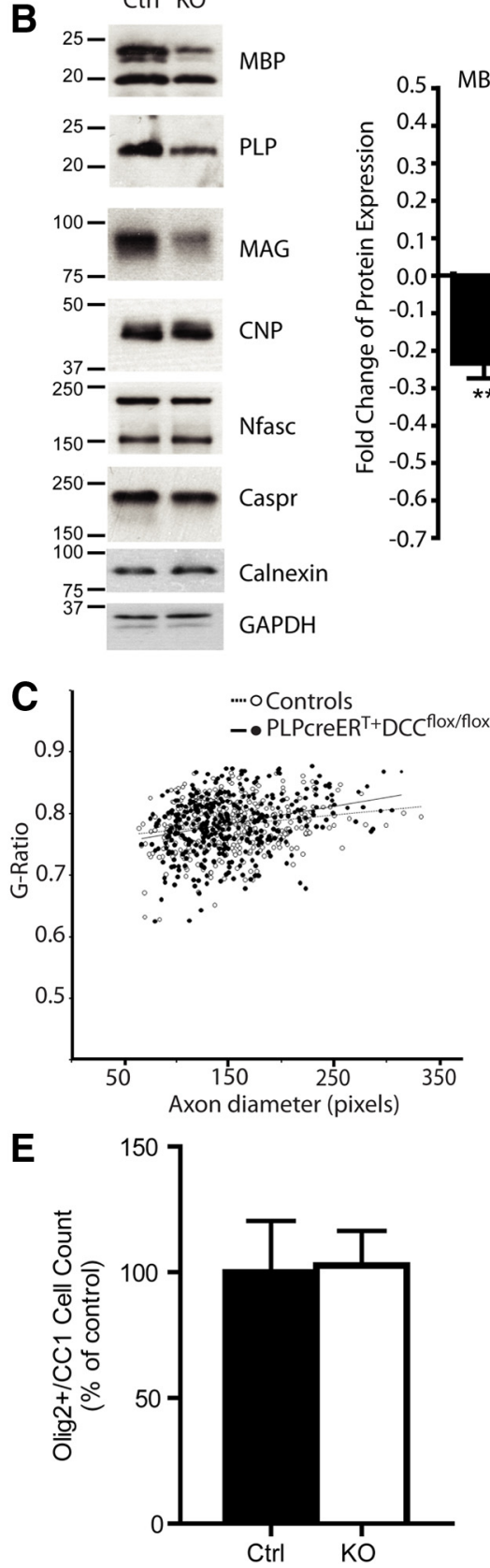

PLPcreER ${ }^{T+D C C \text { flox/flox }}$

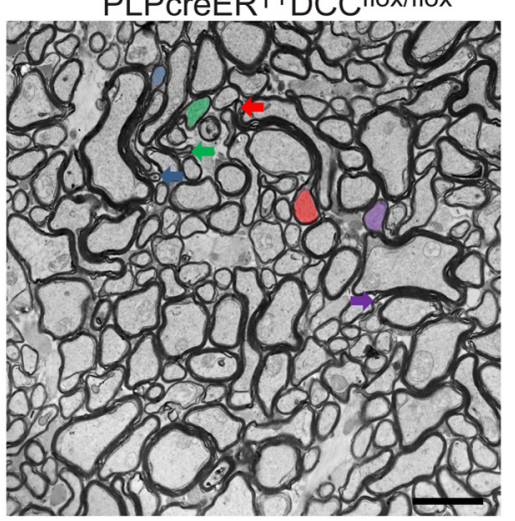

despite the ultrastructural abnormalities detected at paranodes, Caspr domain length was not measurably affected 6 months post induction in any of the four regions examined. In contrast, 9 months following induction, we detected a significant increase in the length of Caspr immunoreactivity in all regions analyzed (Fig. 3C). This diffusion along the axon frequently resulted in overlap between juxtaparanodal Kv1.2 channels and Caspr (Fig. 3B; white arrowhead). These findings indicate that the absence of DCC expression by oligodendrocytes results in the disorganization of axonal domains. Notably, this occurs after defects could be detected in paranodal ultrastructure, revealing a progressive increase in the severity of paranodal disorganization.

\section{Abnormalities in compact myelin architecture and protein content in PLPcreER $^{\mathrm{T}+}$ DCC $^{\text {flox/flox }}$ mice}

We next investigated whether the paranodal defects observed in PLPcreER ${ }^{\mathrm{T}+}$ DCC $^{\text {flox/flox }}$ mice were accompanied by defects in compact myelin. Using electron microscopy, we examined myelin architecture in optic nerve of PLPcreER ${ }^{\mathrm{T}+}$ DCC $^{\text {flox/flox }}$ mice and their control littermates 6 months after tamoxifen induction. In cross sections of optic nerves, we detected a $>3$-fold increase in the number of aberrant myelin outfoldings (Fig. $4 A$; control $=0.60 \% \pm 0.15 \%$, PLPcreER $^{\mathrm{T}+} \mathrm{DCC}^{\text {flox/flox }}=1.93 \% \pm$ $0.26 \%, p=0.0115, n=3)$, indicating that in addition to defects in paranodal ultrastructure, compact myelin exhibits abnormalities in PLPcreER $^{\mathrm{T}+}$ DCC $^{\text {flox/flox }}$ mice.

Given the defects in paranode and compact myelin ultrastructure, we speculated that the absence of DCC might lead to alterations in myelin protein content. We therefore examined myelin proteins in the cerebellum of PLPcreER ${ }^{\mathrm{T}+} \mathrm{DCC}^{\text {flox/flox }}$ mice and control littermates $7-9$ months post

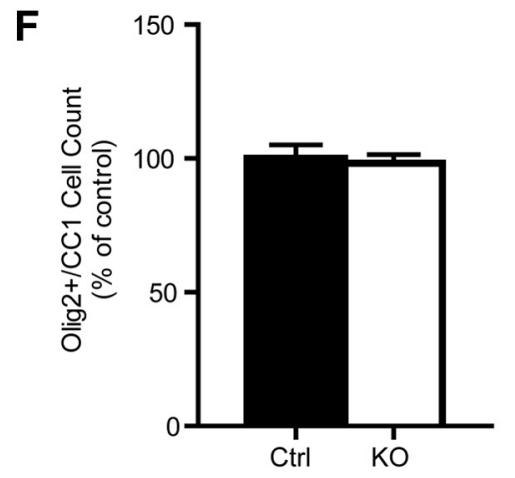

Figure 4. Abnormalities in compact myelin architecture and protein content. $\boldsymbol{A}$, Cross sections of optic nerve were examined 6 months after tamoxifen induction in control and PLPCreER ${ }^{\mathrm{T}+} D C C^{\text {flox/flox }}$ mice. Three times more myelin outfoldings were observed in PLPcreER ${ }^{T+} D C C^{\text {flox/flox }}$ myelin. The colored arrows point to the end of myelin outfoldings corresponding to the same colored

\section{$\leftarrow$}

axon. Scale bar, $2 \mu \mathrm{m}$. B, Representative Western blots and quantification reveal decreased levels of MBP and MAG protein in the cerebellum of PLPcreER ${ }^{T+}$ DCC flox/flox mice compared with their control littermates 7-9 months after induction. Levels of CNP, neurofascin (Nfasc), and Caspr were unaffected $\left(n=5 ;{ }^{* *} p<0.01,{ }^{*} p<0.05 ; t\right.$ test). C, Compared with controls, PLPcreER ${ }^{T+}$ DCC flox/flox mice did not exhibit changes in optic nerve myelin $g$-ratios $6-9$ months after tamoxifen induction ( $n=6$, no effect of age was detected). $\boldsymbol{D}$, No difference in the number of 0lig2/CC1-positive oligodendrocytes was observed in either the spinal cord $(\boldsymbol{E})$ or the optic nerve $(\boldsymbol{F})$ of PLPcreER ${ }^{T+} D C C^{\text {flox/flox }}$ mice compared with controls 9 months after induction $(n=3)$. K0, knock-out. 
induction. MBP and MAG levels were significantly decreased in PLPcreER ${ }^{\mathrm{T}+}$ DCC flox/flox mice, while paranodal and nodal proteins, Caspr and nfasc155/186, were not affected. Although the mean values of PLP protein detected were lower in knock-outs, this change was not significant (Fig. 4B).

To determine whether the altered levels of myelin proteins were due to a change in the thickness of compact myelin, we measured the $g$-ratios of myelin in the optic nerve, excluding axons surrounded by myelin with abnormal outfoldings. We did not detect a significant change in the thickness of myelin sheaths in the absence of DCC expression by oligodendrocytes (Fig. 4C; control = $0.7815 \pm 0.009$, PLPcreER $^{\mathrm{T}+}{ }^{\text {DCC }}$ flox/flox $=0.7839 \pm 0.012 . n=6$ animals/group, 60 axons measured per animal, $p=0.87$, Student's $t$ test). To determine whether a possible loss of oligodendrocytes in PLPcreER ${ }^{\mathrm{T}+}$ DCC $^{\text {flox/flox }}$ mice might account for the alterations in myelin protein content, cell counts were performed in the optic nerve and spinal cord; however, the number of olig2/CC1 double-positive cells did not change in either region 9 months after induction (Fig. 4D-F). We did not detect an increase in the percentage of unmyelinated axons in electron micrograph cross sections of optic nerve in PLPcreER ${ }^{\mathrm{T}+} \mathrm{DCC}^{\text {flox/flox }}$ mice (control $=2.77 \% \pm 0.54 \%$, PLPcreER $^{\mathrm{T}+} \mathrm{DCC}^{\text {flox/flox }}=4.08 \% \pm 0.89 \% ; n=3 ; p=0.28$, Student's $t$ test).

\section{Reduced axon conduction velocity in the CNS of PLPcreER ${ }^{\mathrm{T}+}{ }^{\mathrm{DCC}}{ }^{\text {flox/flox }}$ mice}

To determine whether the myelin defects detected in PLPcreER ${ }^{\mathrm{T}+}$ DCC $^{\text {flox/flox }}$ mice resulted in a measurable impairment of the capacity of CNS axons to conduct action potentials, we assessed axonal conduction velocity along sensory pathways in mice 16 months following induction. An EMG electrode was placed to stimulate the right hamstring muscle of the hind leg and a recording electrode placed in the hindlimb response region of the left primary somatosensory cortex. Figure $5 \mathrm{~A}$ illustrates a representative somatosensory-evoked EEG and the delay measured between stimulation of the right hamstring muscle and the somatosensory response in the left somatosensory cortex. PLPcreER ${ }^{\mathrm{T}+} \mathrm{DCC}^{\text {flox/flox }}$ mice exhibited a significant increase in latency compared with control littermates (Fig. 5B), indicating that the structural and molecular defects observed in the absence of oligodendroglial DCC have functional consequences.

\section{PLPcreER ${ }^{\mathrm{T}+}{ }^{\mathrm{DCC}}{ }^{\text {flox/flox }}$ mice develop deficits in coordination and balance}

Mutations in genes encoding proteins enriched in compact myelin or at paranodal junctions often result in some degree of motor deficit (Bhat et al., 2001; Boyle et al., 2001; Mierzwa et al., 2010). PLPcreER ${ }^{\mathrm{T}+}{ }^{\text {DCC }}{ }^{\text {flox/flox }}$ mice did not exhibit an overt behavioral phenotype. In an open-field test performed 6 months post induction, PLPcreER ${ }^{\mathrm{T}+} \mathrm{DCC}^{\text {flox/flox }}$ mice exhibited normal spontaneous locomotor activity. In a $2 \mathrm{~h}$ test period, they traveled a mean distance that was not significantly different from control littermates, with no difference in duration of activity or average veloc-
B

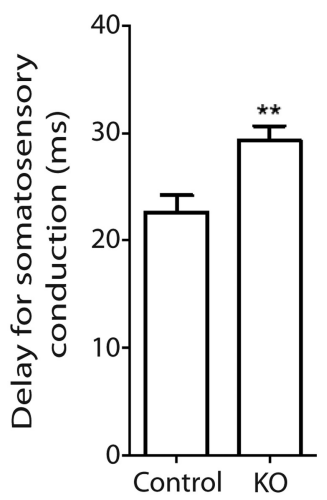

ity detected (Fig. 6A). Muscle strength assessed with the grip test was also normal in PLPcreER ${ }^{\mathrm{T}+} \mathrm{DCC}^{\text {flox/flox }}$ mice compared with controls (Fig. 6B). However, defects in balance and coordination were observed 6 months post induction. PLPcreER ${ }^{\mathrm{T}+} \mathrm{DCC}^{\text {flox } /}$ flox mice took more time to cross a narrow balance beam and reach an enclosed safety platform than control littermates (Fig. $6 C)$. In contrast, when tested 1 month post induction, PLPcreER ${ }^{\mathrm{T}+}$ DCC flox/flox mice performed as well as controls in this task (Fig. 6C). This indicates that the mice develop normally and that this behavioral deficit results from the loss of DCC expression by oligodendrocytes. We also challenged PLPcreER ${ }^{\mathrm{T}+}$ DCC flox/flox mice using the rotarod, another behavioral test that assays motor coordination and balance. Again, PLPcreER ${ }^{\mathrm{T}+}$ DCC $^{\text {flox/flox }}$ mice demonstrated decreased motor performance when tested on an accelerating rotarod 6 months after induction, exhibiting reduced latency to fall compared with control littermates (Fig. 6D). We conclude that the absence of DCC expression by oligodendrocytes results in the development of deficits in coordination and balance.

\section{Discussion}

\section{DCC is required for myelin maintenance}

DCC and its ligand netrin-1 are expressed by neurons and oligodendrocytes (Manitt et al., 2001, 2004), and enriched at paranodes in the mature mammalian CNS (Jarjour et al., 2008). Our earlier studies using organotypic slices provided evidence that neither netrin-1 nor DCC are essential for the initial formation of CNS paranodal junctions, but that both are required to maintain paranodal structure and the organization of the axonal domains associated with nodes of Ranvier (Jarjour et al., 2008). Here, using PLPcreER ${ }^{\mathrm{T}}$ mice to selectively induce cre expression in mature oligodendrocytes in vivo, we addressed the significance of DCC expressed specifically by myelin-forming oligodendrocytes, while sparing effects on OPC migration, oligodendrocyte maturation, and initial myelination. Our findings demonstrate that oligodendroglial DCC contributes to the maintenance of myelin. Selective loss of DCC expression from mature oligodendrocytes resulted in a progressive disruption of paranodal structure and organization, as well as disorganization of compact myelin. Im- 


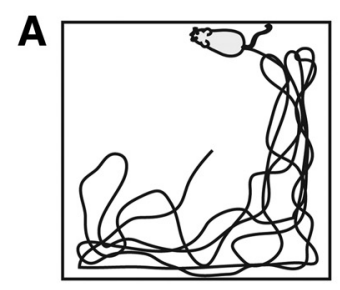

C

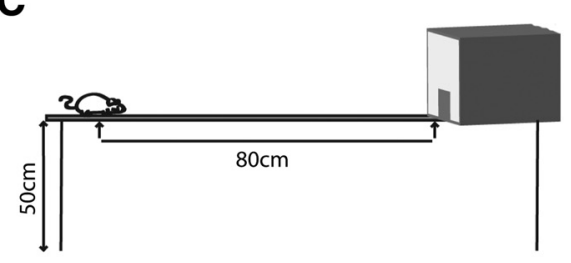

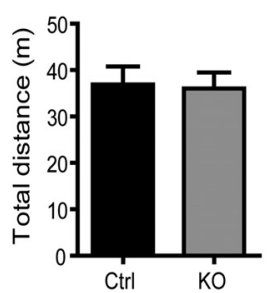
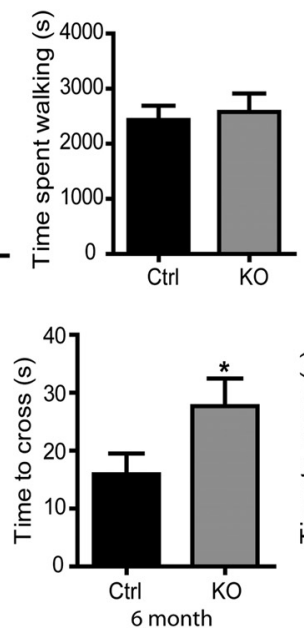

B
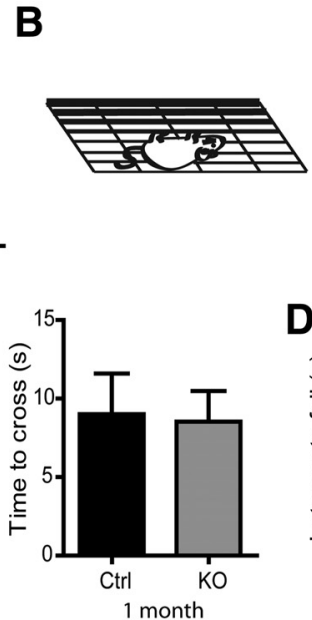

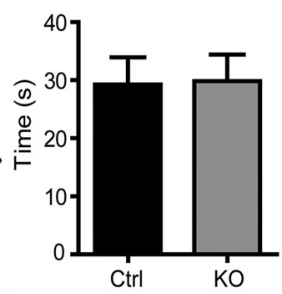

D

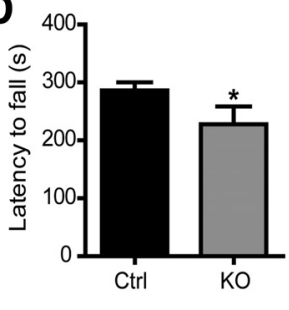

Figure 6. PLPcreER ${ }^{T+} D C C^{\text {flox/flox }}$ mice develop balance and coordination deficits. Different aspects of locomotion were tested 6 months after tamoxifen induction. $\boldsymbol{A}$, Gross motility was normal in PLPcreER ${ }^{\top+}$ DCC ${ }^{\text {flox/flox }}$ mice as tested in the open-field test, assessed by total distance traveled and time spent walking in a $2 \mathrm{~h}$ testing session ( $\left.n=7-8\right)$. $\boldsymbol{B}$, Motor strength was also comparable, as tested with the hanging wire grip test $(n=19-20) . C, P L P C r e E R^{T+} D C C C^{\text {flox/flox }}$ mice exhibited impaired balance and motor coordination 6 months after induction, as tested in the balance beam

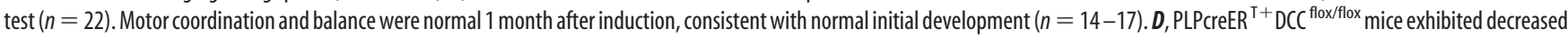
motor performance 6 months after induction when tested on an accelerating rotarod ( $n=9-10$; ${ }^{*} p<0.05$; one-tail $t$ test). K0, knock-out.

portantly, deletion of DCC expression from oligodendrocytes was functionally relevant, resulting in reduced conduction velocity and deficits in coordination and balance.

Although substantial defects were detected, it is likely that ongoing myelination and oligodendrocyte turnover reduced the severity of the loss-of-function phenotype. The PLPcreER ${ }^{\mathrm{T}+}$ DCC $^{\text {flox/flox }}$ mice were induced with tamoxifen at $4.5-6$ weeks of age; however, oligodendrocytes differentiating from OPCs in these mice later in life would express DCC. It has been reported that between 6.5 and $30 \%$ of oligodendrocytes in the adult mouse are generated after 9 weeks of age, depending on the brain region analyzed (Rivers et al., 2008; Zhu et al., 2011; Young et al., 2013), and myelin turnover in the adult CNS has been described (Lasiene et al., 2009). Despite this turnover, our findings reveal that DCC is essential for the maintenance of paranodes and compact myelin.

\section{DCC as an adhesion molecule at the paranode}

The Caspr-contactin-nfasc155 complex is a key player in the organization of paranodal axoglial junctions (Buttermore et al., 2013). Caspr binds in cis to contactin on the axonal membrane, while nfasc155 is expressed by oligodendrocytes on paranodal membrane loops (Rios et al., 2000; Charles et al., 2002). Loss of any of these three proteins prevents the formation of axoglial paranodal junctions, as observed by the absence of transverse bands and failure of paranodal myelin membrane loops to maintain contact with the axon (Bhat et al., 2001; Boyle et al., 2001; Pillai et al., 2009). Mislocalization of these proteins, particularly Caspr, is commonly observed in mice exhibiting paranodal abnormalities (Marcus et al., 2002, 2006; Schaeren-Wiemers et al., 2004; Buttermore et al., 2011). We report that deletion of DCC from myelinating oligodendrocytes results in loss of adhesion between the paranodal loops and the axon, which is followed by a lengthening of the Caspr-immunoreactive domain. Based on these findings, we hypothesize that the absence of DCC results in disruption of the adhesive complex between oligodendrocyte membrane loops and the axonal plasma membrane, freeing a portion of Caspr molecules to diffuse laterally along the axon. Notably, we did not detect defects in the interaction between oligodendrocyte membrane loops, indicating that DCC is not essential for adhesion between the glial loops at paranodes. Furthermore, our findings indicate that the nfasc155-Casprcontactin complex is not sufficient to maintain paranodal organization. We propose that DCC and netrin-1 may function in parallel as an adhesive complex that links the oligodendroglial loops to the axon. It is also possible that DCC may influence the localization of nfasc 155 or signal to facilitate nfasc 155 function to promote paranodal organization. Since relatively little is known of DCC or nfasc155 signaling in oligodendrocytes, additional studies are required to elucidate the underlying mechanisms involved.

Our findings reveal that the loss of DCC expression by oligodendrocytes results in readily detectable changes in the ultrastructural organization of paranodal loops. Notably, the ultrastructural defects were first detected at 6 months postinduction, a time point at which the paranodal distribution of Caspr appeared normal. Later, at 9 months post-induction, lengthening of the distribution of Caspr was detected. The ultrastructural changes that precede the mislocalization of Caspr indicate that loss of DCC function by mature oligodendrocytes results in defects that become progressively worse with age. These findings also highlight the importance of maintaining tight adhesion between the paranodal myelin loops and the axon to maintain axonal domain organization, reinforcing the model in which the paranode functions as a molecular barrier that limits the lateral diffusion of proteins localized to the node, paranode, and juxtaparanode (Pedraza et al., 2001; Poliak and Peles, 2003).

Multiple studies have identified short-range roles for DCC and netrin-1 regulating cell-cell interactions and adhesion (for review, see Baker et al., 2006). Although netrin-1 is a secreted protein, most netrin-1 in the CNS is not freely soluble, but membrane associated (Manitt et al., 2001), consistent with the restricted distribution of netrin-1 at paranodes (Jarjour et al., 2008). Disrupting DCC function blocks cell adhesion to substrate bound netrin-1 (Shekarabi et al., 2005; Moore et al., 2008), and recent studies indicate that mechanical attachment of netrin- 1 to a substrate is necessary to generate the force required for chemoattraction (Moore et al., 2009, 2012). These findings are consistent with netrin-1 and DCC contributing directly to adhesion between the axonal plasma membrane and oligodendrocyte paranodal loops. 


\section{Beyond the paranode: evidence for a broader role of DCC in myelin}

In addition to disorganized paranodal loops, we detected compact myelin outfoldings and reduced amounts of MAG and MBP protein in aged PLPcreER ${ }^{\mathrm{T}+} \mathrm{DCC}^{\text {flox/flox }}$ mice. The underlying cause of these internodal myelin deficits is not clear. While DCC is concentrated at the paranode, it may also be present and influence the organization of other compartments of noncompact CNS myelin, such as the adaxonal or abaxonal membrane. For example, in PNS myelin, DCC was detected outside Schwann cell paranodes at Schmidt-Lantermann incisures (Webber et al., 2011). Surprisingly, the decreased levels of MBP and MAG protein detected in aged PLPcreER ${ }^{\mathrm{T}+} \mathrm{DCC}^{\text {flox/flox }}$ mice did not correlate with changes in $g$-ratio or in the percentage of myelinated axons. While this may seem unexpected, a previous study reported no effect on the percentage of myelinated axons or myelin thickness until $>50 \%$ of MBP protein was lost (Shine et al., 1992). Still, the decreased levels of protein detected may have consequences for myelin stability and contribute to the structural defects observed at paranodes and compact myelin in PLPcreER $^{\mathrm{T}+}$ DCC $^{\text {flox/flox }}$ mice.

It is possible that the myelin outfoldings and changes in myelin protein levels detected result from a primary defect in paranodal organization, which subsequently spreads to the internode to disrupt the stability of compact myelin. Alternatively, loss of DCC signaling may directly affect myelin stability via regulation of myelin protein translation or turnover, which could lead to the paranodal defects identified. DCC regulates src family kinase signaling and activation of the RhoGTPases cdc42, rac1, and rhoA to direct cytoskeletal organization (Lai Wing Sun et al., 2011). Loss of cdc42 or racl in oligodendrocytes results in the disorganization of compact and noncompact myelin membranes, including the formation of aberrant myelin outfoldings (Thurnherr et al., 2006), while loss of the src family kinase fyn results in hypomyelination (Sperber et al., 2001). Although the outfolded myelin found in the PLPcreER ${ }^{\mathrm{T}+} \mathrm{DCC}^{\text {flox/flox }}$ mice appears similar to what was detected in the cdc42 and racl conditional knock-outs, previous work has shown that the DCC-dependent morphological response of oligodendrocytes to netrin-1 during maturation in vitro is independent of cdc42 or racl activation (Rajasekharan et al., 2009). However, changes in Rho GTPase signaling mediated by DCC have been described during oligodendrocyte maturation (Rajasekharan et al., 2010), and it remains possible that DCC may regulate $\mathrm{cdc} 42$ and $\mathrm{racl}$ in mature myelinating oligodendrocytes in vivo.

Signaling downstream of DCC may also be linked to the detected decreased levels of MBP and MAG protein observed. Fyn, which is recruited to and activated downstream of DCC in oligodendrocytes (Rajasekharan et al., 2009), regulates the local translation of MBP (Lu et al., 2005; White et al., 2008). Interestingly, netrin-1 and DCC directly regulate local translation in other cell types (Campbell and Holt, 2001; Leung et al., 2006; Tcherkezian et al., 2010; Goldman et al., 2013) and deregulation of such signal transduction mechanisms in mature myelinating oligodendrocytes may contribute to the phenotypes reported here.

\section{Implication in aging and disease}

Deficits in the maintenance of paranodal junctions and the stability of compact myelin are thought to underlie the onset of a number of pathological conditions. For example, myelin instability has been proposed to contribute to cognitive deficits associated with aging (Bartzokis, 2004). Paranodal defects have also been proposed to constitute a predisposition to neuroinflamma- tion leading to the development of demyelinating diseases such as multiple sclerosis (MS; Mastronardi and Moscarello, 2005). The disruption of paranodal junctions has been identified as an early sign of demyelination around MS lesions (Wolswijk and Balesar, 2003; Howell et al., 2006). Notably, a recent proteomic analysis of CSF samples collected from children during their initial presentation of CNS inflammation, who were subsequently diagnosed as having MS, identified elevated levels of proteins enriched at the node of Ranvier and paranodal junction, including elevated levels of DCC, but did not detect compact myelin proteins (Dhaunchak et al., 2012). These studies suggest that the paranode is a particularly vulnerable point along myelinated axons susceptible to degeneration and immune attack, and that damage at the paranode may precede degeneration of compact myelin and demyelination (Desmazières et al., 2012). Identifying and understanding the molecular mechanisms that promote the stability and maintenance of myelin is thus tremendously important to developing therapeutic strategies to treat and ultimately prevent demyelinating disease.

\section{References}

Araki K, Araki M, Miyazaki J, Vassalli P (1995) Site-specific recombination of a transgene in fertilized eggs by transient expression of Cre recombinase. Proc Natl Acad Sci U S A 92:160-164. CrossRef Medline

Baker KA, Moore SW, Jarjour AA, Kennedy TE (2006) When a diffusible axon guidance cue stops diffusing: roles for netrins in adhesion and morphogenesis. Curr Opin Neurobiol 16:529-534. CrossRef Medline

Bartzokis G (2004) Age-related myelin breakdown: a developmental model of cognitive decline and Alzheimer's disease. Neurobiol Aging 25:5-18, 2004; author reply 49-62. Medline

Bhat MA, Rios JC, Lu Y, Garcia-Fresco GP, Ching W, St Martin M, Li J, Einheber S, Chesler M, Rosenbluth J, Salzer JL, Bellen HJ (2001) Axonglia interactions and the domain organization of myelinated axons requires neurexin IV/Caspr/Paranodin. Neuron 30:369-383. CrossRef Medline

Bonnon C, Bel C, Goutebroze L, Maigret B, Girault JA, Faivre-Sarrailh C (2007) PGY repeats and N-glycans govern the trafficking of paranodin and its selective association with contactin and neurofascin-155. Mol Biol Cell 18:229-241. Medline

Boyle ME, Berglund EO, Murai KK, Weber L, Peles E, Ranscht B (2001) Contactin orchestrates assembly of the septate-like junctions at the paranode in myelinated peripheral nerve. Neuron 30:385-397. CrossRef Medline

Buttermore ED, Dupree JL, Cheng J, An X, Tessarollo L, Bhat MA (2011) The cytoskeletal adaptor protein band $4.1 \mathrm{~B}$ is required for the maintenance of paranodal axoglial septate junctions in myelinated axons. J Neurosci 31:8013-8024. CrossRef Medline

Buttermore ED, Thaxton CL, Bhat MA (2013) Organization and maintenance of molecular domains in myelinated axons. J Neurosci Res 91:603622. CrossRef Medline

Campbell DS, Holt CE (2001) Chemotropic responses of retinal growth cones mediated by rapid local protein synthesis and degradation. Neuron 32:1013-1026. CrossRef Medline

Carter RJ, Lione LA, Humby T, Mangiarini L, Mahal A, Bates GP, Dunnett SB, Morton AJ (1999) Characterization of progressive motor deficits in mice transgenic for the human Huntington's disease mutation. J Neurosci 19:3248-3257. Medline

Charles P, Tait S, Faivre-Sarrailh C, Barbin G, Gunn-Moore F, DenisenkoNehrbass N, Guennoc AM, Girault JA, Brophy PJ, Lubetzki C (2002) Neurofascin is a glial receptor for the paranodin/Caspr-contactin axonal complex at the axoglial junction. Curr Biol 12:217-220. CrossRef Medline

Coetzee T, Fujita N, Dupree J, Shi R, Blight A, Suzuki K, Suzuki K, Popko B (1996) Myelination in the absence of galactocerebroside and sulfatide: normal structure with abnormal function and regional instability. Cell 86:209-219. CrossRef Medline

Desmazières A, Sol-Foulon N, Lubetzki C (2012) Changes at the nodal and perinodal axonal domains: a basis for multiple sclerosis pathology? Mult Scler 18:133-137. CrossRef Medline

Dhaunchak AS, Becker C, Schulman H, De Faria O Jr, Rajasekharan S, Ban- 
well B, Colman DR, Bar-Or A, Canadian Pediatric Demyelinating Disease Group (2012) Implication of perturbed axoglial apparatus in early pediatric multiple sclerosis. Ann Neurol 71:601-613. CrossRef Medline

Doerflinger NH, Macklin WB, Popko B (2003) Inducible site-specific recombination in myelinating cells. Genesis 35:63-72. CrossRef Medline

Dupree JL, Coetzee T, Blight A, Suzuki K, Popko B (1998) Myelin galactolipids are essential for proper node of Ranvier formation in the CNS. J Neurosci 18:1642-1649. Medline

Fazeli A, Dickinson SL, Hermiston ML, Tighe RV, Steen RG, Small CG, Stoeckli ET, Keino-Masu K, Masu M, Rayburn H, Simons J, Bronson RT, Gordon JI, Tessier-Lavigne M, Weinberg RA (1997) Phenotype of mice lacking functional Deleted in colorectal cancer (Dcc) gene. Nature 386: 796-804. CrossRef Medline

Foran DR, Peterson AC (1992) Myelin acquisition in the central nervous system of the mouse revealed by an MBP-Lac Z transgene. J Neurosci 12:4890-4897. Medline

Fruttiger M, Montag D, Schachner M, Martini R (1995) Crucial role for the myelin-associated glycoprotein in the maintenance of axon-myelin integrity. Eur J Neurosci 7:511-515. CrossRef Medline

Goldman JS, Ashour MA, Magdesian MH, Tritsch NX, Harris SN, Christofi N, Chemali R, Stern YE, Thompson-Steckel G, Gris P, Glasgow SD, Grutter P, Bouchard JF, Ruthazer ES, Stellwagen D, Kennedy TE (2013) Netrin-1 promotes excitatory synaptogenesis between cortical neurons by initiating synapse assembly. J Neurosci 33:17278-17289. CrossRef Medline

Hamano K, Takeya T, Iwasaki N, Nakayama J, Ohto T, Okada Y (1998) A quantitative study of the progress of myelination in the rat central nervous system, using the immunohistochemical method for proteolipid protein. Brain Res Dev Brain Res 108:287-293. CrossRef Medline

Hedstrom KL, Ogawa Y, Rasband MN (2008) AnkyrinG is required for maintenance of the axon initial segment and neuronal polarity. J Cell Biol 183:635-640. CrossRef Medline

Howell OW, Palser A, Polito A, Melrose S, Zonta B, Scheiermann C, Vora AJ, Brophy PJ, Reynolds R (2006) Disruption of neurofascin localization reveals early changes preceding demyelination and remyelination in multiple sclerosis. Brain 129:3173-3185. CrossRef Medline

Jarjour AA, Manitt C, Moore SW, Thompson KM, Yuh SJ, Kennedy TE (2003) Netrin-1 is a chemorepellent for oligodendrocyte precursor cells in the embryonic spinal cord. J Neurosci 23:3735-3744. Medline

Jarjour AA, Bull SJ, Almasieh M, Rajasekharan S, Baker KA, Mui J, Antel JP, Di Polo A, Kennedy TE (2008) Maintenance of axo-oligodendroglial paranodal junctions requires DCC and netrin-1. J Neurosci 28:1100311014. CrossRef Medline

Krimpenfort P, Song JY, Proost N, Zevenhoven J, Jonkers J, Berns A (2012) Deleted in colorectal carcinoma suppresses metastasis in p53-deficient mammary tumours. Nature 482:538-541. CrossRef Medline

Lai Wing Sun K, Correia JP, Kennedy TE (2011) Netrins: versatile extracellular cues with diverse functions. Development 138:2153-2169. CrossRef Medline

Lappe-Siefke C, Goebbels S, Gravel M, Nicksch E, Lee J, Braun PE, Griffiths IR, Nave KA (2003) Disruption of Cnp1 uncouples oligodendroglial functions in axonal support and myelination. Nat Genet 33:366-374. CrossRef Medline

Lasiene J, Matsui A, Sawa Y, Wong F, Horner PJ (2009) Age-related myelin dynamics revealed by increased oligodendrogenesis and short internodes. Aging Cell 8:201-213. CrossRef Medline

Leung KM, van Horck FP, Lin AC, Allison R, Standart N, Holt CE (2006) Asymmetrical beta-actin mRNA translation in growth cones mediates attractive turning to netrin-1. Nat Neurosci 9:1247-1256. CrossRef Medline

Lu Z, Ku L, Chen Y, Feng Y (2005) Developmental abnormalities of myelin basic protein expression in fyn knock-out brain reveal a role of Fyn in posttranscriptional regulation. J Biol Chem 280:389-395. CrossRef Medline

Manitt C, Colicos MA, Thompson KM, Rousselle E, Peterson AC, Kennedy TE (2001) Widespread expression of netrin-1 by neurons and oligodendrocytes in the adult mammalian spinal cord. J Neurosci 21:3911-3922. Medline

Manitt C, Thompson KM, Kennedy TE (2004) Developmental shift in expression of netrin receptors in the rat spinal cord: predominance of UNC-5 homologues in adulthood. J Neurosci Res 77:690-700. CrossRef Medline
Marcus J, Dupree JL, Popko B (2002) Myelin-associated glycoprotein and myelin galactolipids stabilize developing axo-glial interactions. J Cell Biol 156:567-577. CrossRef Medline

Marcus J, Honigbaum S, Shroff S, Honke K, Rosenbluth J, Dupree JL (2006) Sulfatide is essential for the maintenance of CNS myelin and axon structure. Glia 53:372-381. CrossRef Medline

Mastronardi FG, Moscarello MA (2005) Molecules affecting myelin stability: a novel hypothesis regarding the pathogenesis of multiple sclerosis. J Neurosci Res 80:301-308. CrossRef Medline

Michalski JP, Anderson C, Beauvais A, De Repentigny Y, Kothary R (2011) The proteolipid protein promoter drives expression outside of the oligodendrocyte lineage during embryonic and early postnatal development. PLoS One 6:e19772. CrossRef Medline

Mierzwa AJ, Arevalo JC, Schiff R, Chao MV, Rosenbluth J (2010) Role of transverse bands in maintaining paranodal structure and axolemmal domain organization in myelinated nerve fibers: effect on longevity in dysmyelinated mutant mice. J Comp Neurol 518:2841-2853. CrossRef Medline

Mombaerts P, Wang F, Dulac C, Chao SK, Nemes A, Mendelsohn M, Edmondson J, Axel R (1996) Visualizing an olfactory sensory map. Cell 87:675-686. CrossRef Medline

Moore SW, Correia JP, Lai Wing Sun K, Pool M, Fournier AE, Kennedy TE (2008) Rho inhibition recruits DCC to the neuronal plasma membrane and enhances axon chemoattraction to netrin 1. Development 135:28552864. CrossRef Medline

Moore SW, Biais N, Sheetz MP (2009) Traction on immobilized netrin-1 is sufficient to reorient axons. Science 325:166. CrossRef Medline

Moore SW, Zhang X, Lynch CD, Sheetz MP (2012) Netrin-1 attracts axons through FAK-dependent mechanotransduction. J Neurosci 32:1157411585. CrossRef Medline

Pedraza L, Huang JK, Colman DR (2001) Organizing principles of the axoglial apparatus. Neuron 30:335-344. CrossRef Medline

Pillai AM, Thaxton C, Pribisko AL, Cheng JG, Dupree JL, Bhat MA (2009) Spatiotemporal ablation of myelinating glia-specific neurofascin (Nfasc NF155) in mice reveals gradual loss of paranodal axoglial junctions and concomitant disorganization of axonal domains. J Neurosci Res 87:17731793. CrossRef Medline

Poliak S, Peles E (2003) The local differentiation of myelinated axons at nodes of Ranvier. Nat Rev Neurosci 4:968-980. CrossRef Medline

Rajasekharan S, Baker KA, Horn KE, Jarjour AA, Antel JP, Kennedy TE (2009) Netrin 1 and Dcc regulate oligodendrocyte process branching and membrane extension via Fyn and RhoA. Development 136:415-426. CrossRef Medline

Rajasekharan S, Bin JM, Antel JP, Kennedy TE (2010) A central role for RhoA during oligodendroglial maturation in the switch from netrin-1mediated chemorepulsion to process elaboration. J Neurochem 113: 1589-1597. CrossRef Medline

Richardson WD, Young KM, Tripathi RB, McKenzie I (2011) NG2-glia as multipotent neural stem cells: fact or fantasy? Neuron 70:661-673. CrossRef Medline

Rios JC, Melendez-Vasquez CV, Einheber S, Lustig M, Grumet M, Hemperly J, Peles E, Salzer JL (2000) Contactin-associated protein (Caspr) and contactin form a complex that is targeted to the paranodal junctions during myelination. J Neurosci 20:8354-8364. Medline

Rivers LE, Young KM, Rizzi M, Jamen F, Psachoulia K, Wade A, Kessaris N, Richardson WD (2008) PDGFRA/NG2 glia generate myelinating oligodendrocytes and piriform projection neurons in adult mice. Nat Neurosci 11:1392-1401. CrossRef Medline

Sango K, McDonald MP, Crawley JN, Mack ML, Tifft CJ, Skop E, Starr CM, Hoffmann A, Sandhoff K, Suzuki K, Proia RL (1996) Mice lacking both subunits of lysosomal beta-hexosaminidase display gangliosidosis and mucopolysaccharidosis. Nat Genet 14:348-352. CrossRef Medline

Schaeren-Wiemers N, Bonnet A, Erb M, Erne B, Bartsch U, Kern F, Mantei N, Sherman D, Suter U (2004) The raft-associated protein MAL is required for maintenance of proper axon-glia interactions in the central nervous system. J Cell Biol 166:731-742. CrossRef Medline

Schwenk F, Baron U, Rajewsky K (1995) A cre-transgenic mouse strain for the ubiquitous deletion of loxP-flanked gene segments including deletion in germ cells. Nucleic Acids Res 23:5080-5081. CrossRef Medline

Serafini T, Colamarino SA, Leonardo ED, Wang H, Beddington R, Skarnes WC, Tessier-Lavigne M (1996) Netrin-1 is required for commissural 
axon guidance in the developing vertebrate nervous system. Cell 87:10011014. CrossRef Medline

Shatzmiller RA, Goldman JS, Simard-Emond L, Rymar V, Manitt C, Sadikot AF, Kennedy TE (2008) Graded expression of netrin-1 by specific neuronal subtypes in the adult mammalian striatum. Neuroscience 157:621636. CrossRef Medline

Shekarabi M, Moore SW, Tritsch NX, Morris SJ, Bouchard JF, Kennedy TE (2005) Deleted in colorectal cancer binding netrin-1 mediates cell substrate adhesion and recruits Cdc42, Racl, Pak1, and N-WASP into an intracellular signaling complex that promotes growth cone expansion. J Neurosci 25:3132-3141. CrossRef Medline

Shepherd MN, Pomicter AD, Velazco CS, Henderson SC, Dupree JL (2012) Paranodal reorganization results in the depletion of transverse bands in the aged central nervous system. Neurobiol Aging 33:203.e213-e224. CrossRef Medline

Sherman DL, Tait S, Melrose S, Johnson R, Zonta B, Court FA, Macklin WB, Meek S, Smith AJ, Cottrell DF, Brophy PJ (2005) Neurofascins are required to establish axonal domains for saltatory conduction. Neuron 48: 737-742. CrossRef Medline

Shine HD, Readhead C, Popko B, Hood L, Sidman RL (1992) Morphometric analysis of normal, mutant, and transgenic CNS: correlation of myelin basic protein expression to myelinogenesis. J Neurochem 58:342-349. CrossRef Medline

Soriano P (1999) Generalized lacZ expression with the ROSA26 Cre reporter strain. Nat Genet 21:70-71. CrossRef Medline

Sperber BR, Boyle-Walsh EA, Engleka MJ, Gadue P, Peterson AC, Stein PL, Scherer SS, McMorris FA (2001) A unique role for Fyn in CNS myelination. J Neurosci 21:2039-2047. Medline

Tait S, Gunn-Moore F, Collinson JM, Huang J, Lubetzki C, Pedraza L, Sherman DL, Colman DR, Brophy PJ (2000) An oligodendrocyte cell adhe- sion molecule at the site of assembly of the paranodal axo-glial junction. J Cell Biol 150:657-666. CrossRef Medline

Tcherkezian J, Brittis PA, Thomas F, Roux PP, Flanagan JG (2010) Transmembrane receptor DCC associates with protein synthesis machinery and regulates translation. Cell 141:632-644. CrossRef Medline

Thurnherr T, Benninger Y, Wu X, Chrostek A, Krause SM, Nave KA, Franklin RJ, Brakebusch C, Suter U, Relvas JB (2006) Cdc42 and Racl signaling are both required for and act synergistically in the correct formation of myelin sheaths in the CNS. J Neurosci 26:10110-10119. CrossRef Medline

Tsai HH, Tessier-Lavigne M, Miller RH (2003) Netrin 1 mediates spinal cord oligodendrocyte precursor dispersal. Development 130:2095-2105. CrossRef Medline

Webber CA, Christie KJ, Cheng C, Martinez JA, Singh B, Singh V, Thomas D, Zochodne DW (2011) Schwann cells direct peripheral nerve regeneration through the Netrin-1 receptors, DCC and Unc5H2. Glia 59:1503-1517. CrossRef Medline

White R, Gonsior C, Krämer-Albers EM, Stöhr N, Hüttelmaier S, Trotter J (2008) Activation of oligodendroglial Fyn kinase enhances translation of mRNAs transported in hnRNP A2-dependent RNA granules. J Cell Biol 181:579-586. CrossRef Medline

Wolswijk G, Balesar R (2003) Changes in the expression and localization of the paranodal protein Caspr on axons in chronic multiple sclerosis. Brain 126:1638-1649. CrossRef Medline

Young KM, Psachoulia K, Tripathi RB, Dunn SJ, Cossell L, Attwell D, Tohyama K, Richardson WD (2013) Oligodendrocyte dynamics in the healthy adult CNS: evidence for myelin remodeling. Neuron 77:873-885. CrossRef Medline

Zhu X, Hill RA, Dietrich D, Komitova M, Suzuki R, Nishiyama A (2011) Age-dependent fate and lineage restriction of single NG2 cells. Development 138:745-753. CrossRef Medline 